\title{
Shop till you drop? Venue choices of business and non-business interests in the European Union
}

\author{
Dominic Pakull $^{1}$ (D) David Marshall ${ }^{2} \cdot$ Patrick Bernhagen $^{1}$
}

Published online: 15 July 2020

(c) The Author(s) 2020

\begin{abstract}
The EU offers a variety of access points through which interest groups can attempt to influence policy-making. In this paper, we analyze differences in the use of these access points, or venues, by interest groups. Considering the roles played by different EU institutions along the policy cycle, we argue that the venues differ by the extent to which they encourage lobbying from different interest groups. Analyzing survey responses by more than 700 European interest associations, we find that the distribution of access-seeking by business and non-business actors differs across venues. Reflecting its pivotal role at the pre-proposal stage, the Commission encourages non-business organizations to spend much of their finite lobbying resources. In the context of the European Parliament, non-business groups are not only interested in influencing its decisions, but also in connecting to ordinary Members of the European Parliament. Business groups, for their part, apply greater resources to the rapporteurs. Finally, we show that business groups also allocate their resources to regulatory agencies at the implementation stage in the policy process, where incomplete legislative contracts are finalized and non-business groups' resources are depleted.
\end{abstract}

Keywords Business organizations · Venue shopping · Interest groups · European Union institutions

\section{Introduction}

The European Union (EU), like many Western political systems, is facing a crisis of legitimacy. The European model is challenged by Eurosceptic forces (Treib 2014), and its problem-solving capacity is regarded as an important precondition to regain

Dominic Pakull

dominic.pakull@sowi.uni-stuttgart.de

1 Department of Political Science and Political Sociology, Institute for Social Sciences, University of Stuttgart, Breitscheidstraße 2, 70174 Stuttgart, Germany

2 Department of Politics and International Relations, University of Reading, Whiteknights, RG6 6AA Reading, Germany 
the trust of its citizens (De Angelis 2017). Against this background, interest groups, especially non-business organizations, get into the spotlight as they might increase both the output and input legitimacy of the EU's political system (Kohler-Koch 2010). Accessing policy-makers is a precondition for the capability of these organizations to influence policy. Recognizing this, over the past two decades the European Commission (2001) has put extensive efforts into levelling the playing field for organized - especially non-business - interests. In this paper, we investigate the extent to which these efforts are matched by the access-seeking strategies of interest groups.

Access-seeking is part of a strategy of inside lobbying by interest groups attempting to influence public policy (Bouwen 2004; Hansen 1991). As Truman (1951: 264) pointed out, access is a necessary, but not a sufficient condition to influence policies: "Power of any kind cannot be reached by a political interest group, or its leaders, without access to one or more key points of decision in the government". Apart from cases where policy-makers contact interest groups directly themselves, seeking access is a precondition for gaining influence (Schlozman and Tierney 1986). In respect to state-society relations, it is therefore important to know how business and non-business actors differ in their strategies: If business actors wield disproportionate power over political outcomes, then political equality and democratic accountability are undermined (Dahl 1989: 324-328).

For organized groups pursuing insider strategies, the question arises which policy-making venues they should target. Following Baumgartner and Jones (1991: 32), we define policy venues as the institutional locations where authoritative decisions are made concerning a given issue. In Brussels, policy-making occurs across a range of venues that interest groups can target, obliging them to choose which venues to concentrate their lobbying efforts on. In the EU, power is even more dispersed than in the highly fragmented political system of the US (Hull 1993: 85). Thus, interest groups can target multiple venues to pursue their goals. It is this process of venue shopping (Baumgartner and Jones 2009), or venue choice, that we seek to explain in respect to both business and non-business organizations. To this end, we analyze differences in lobbying behavior across the EU intuitions with their different roles in the policy cycle.

Our investigation makes several contributions to the literature on EU politics and political advocacy. Firstly, if there are systematic differences between the access seeking strategies of business and non-business groups, this might lead to differential access to political actors and hence affect the opportunities groups have to apply influence at a given stage in the process. Specifically, business actors are often considered to enjoy privileged access to policy-makers (Knoke et al. 1996; Su et al. 1995). Secondly, while organizations are relatively free to lobby across venues, the opportunities to affect policy outcomes vary between venues. For example, consistent with the literature on national-level lobbying (Grant 2000; Hall and Wayman 1990; Richardson and Jordan 1979), lobbying early in the policy-making process and trying to influence the Commission at the pre-proposal (consultation) stage, is generally considered to be more effective than lobbying at subsequent stages in the process (Bouwen 2009; Hull 1993). Thirdly, while existing studies have investigated the strategies of gaining/seeking access at the European level (Hanegraaff and 
Berkhout 2019; Beyers 2004) or from a multi-level perspective (Ehrlich and Jones 2017; Kohler-Koch et al. 2017; Dür and Mateo 2016), our research design allows us to compare systematically the lobbying efforts of both business and non-business organizations at venues pivotal to all stages of the EU policy-making process (pre and post legislative). For this purpose, we can use data from an online survey with responses from 734 European interest groups on how frequently they sought access to a broad range of venues at the EU level. Thus, we can investigate access-seeking strategies at the crucial desk levels of both the Commission (DGs) and Council (Coreper); two different venues within the Parliament; and regulatory agencies. The latter can be considered to function as supranational agents in order to solve problems of incomplete contracting in the legislative process (Pollack 1997), in which not every detail can be regulated nor every future conflict caused by the law be foreseen. In order to analyze if business and non-business groups are more or less likely to target a specific venue, we conduct a multivariate analysis for each of the venues. In this way we can comprehensively analyze lobbying efforts along the whole policy cycle from pre-proposal to the implementation stage.

In addition to comparing the access-seeking strategies of business and non-business groups, we can further analyze how the concentration of lobbying effort at one venue could affect choices at others. Furthermore, we look at the European Parliament in a more differentiated way by distinguishing between rapporteurs and ordinary MEPs. In this way, we can qualify and contextualize studies that have found that the Parliament is more open to non-business interests (Dür et al. 2019; Lehmann 2009). Our findings suggest that there is no business advantage at the level of the Commission. However, while business and non-business groups actively participate during the consultation phase-with the latter benefiting from Commission efforts to level the playing field - the effect is to deplete the relatively limited resources of non-business actors, thereby advantaging business at subsequent stages of the policy process, in particular during implementation by regulatory agencies.

\section{Venue shopping in the multi-level system of the EU}

Interest groups can be broadly categorized as business and other interests (Walker 1991). If groups have a comparative advantage in material resources compared to their opponents, they are able to develop more appealing interpretations of their positions to policy-makers (Smith 1984: 49). In general, business actors possess greater material resources, which increases their chances of accessing policy-makers. Moreover, the more resource-rich groups are, the larger the number and variety of venues they can target (Holyoke et al. 2012: 13). Furthermore, the ability of interest groups to offer useful information concerning policy consequences is a key component of gaining access (Hall and Deardorff 2006; Ainsworth 1993; Austen-Smith 1993). Often technical, such information is important to European institutions, especially the European Commission, given its relatively low bureaucratic capacities (Broscheid and Coen 2003: 167). Technical information is helpful to political actors to decide on the details when drafting legislation (Bouwen 2004: 346). Thus, technical 
knowledge is another important resource business groups possess, and arguably one that they avail of to a greater extent than other groups (Bernhagen 2007). However, policy-makers also demand political information on public support or opposition for a piece of legislation. This holds true especially for the European Parliament (Dür et al. 2019; De Bruycker 2016).

Several studies have analyzed groups' strategies to seek and gain access to different venues in the EU from a multi-level perspective (Ehrlich and Jones 2017; Dür and Mateo 2016; Beyers 2002). They distinguish a national route where organizations lobby national-level institutions to influence European policy-making, and a Brussels route where they directly target actors and institutions at the supranational level. Beyers (2004) analyzes differences in the inside lobbying strategies between "specific" and "diffuse" interests in these venues: Directorate Generals (DGs) and cabinets of the European Commission, Members of the European Parliament (MEPs), advisory bodies-the European Economic and Social Committee and the Committee of the Regions-as well as the Council (Permanent Representations and the Council secretariat). He defines specific interests analogous to Beer's (1965) "producer groups" (i.e., as business associations and trade unions). "Diffuse interests" link broad and general segments of society lacking such a specific and concentrated constituency (Beyers 2004: 216). No differences in the inside lobbying strategies of diffuse and specific interests are found, with both forms lobbying the European Commission and Parliament most frequently, and the member-state representatives in the Council to a lesser extent. However, while analytically sharp, this classification prohibits the possibility of distinguishing between employer and employee organizations, since both are producer groups.

The literature on gaining access to policy-makers yields interesting results on the success of inside lobbying. Analyzing contacts between organized interests and policy-makers in Austria, Germany, Ireland, Lithuania and Spain, Dür and Mateo (2016) find that business associations at both the European and national level have an advantage over other types of associations regarding access to executive institutions. However, business groups do not gain significantly more access to legislative institutions than other interest groups at the European and national level. In a recent study, Hanegraaff and Berkhout (2019) find that the distribution among business groups and non-business groups is similar across the venues of both the Commission and the European Parliament. Kohler-Koch et al. (2017) analyze the access-seeking strategies of national business associations both to national as well as to European institutions. They find that the more financial resources an organization possesses, the more likely it is to gain access to an institution. This applies especially to European compared to national institutions, where it is of less importance. These partly diverging findings underline the importance of studying strategies of inside lobbying, i.e., access-seeking. Our research design enables us to evaluate these findings regarding strategies of inside lobbying by European interest groups to EU institutions, including two different venues within the European Parliament. In the next section, we develop theoretical expectations about the advocacy strategies of business and non-business groups. 


\section{Strategies of inside lobbying}

At the European level, a variety of venues provide opportunities for interest groups to influence policies (Princen and Kerremans 2008). The process formally begins with the European Commission, which has the sole right to initiate legislation. Due to its consultation regime, a wide variety of interests have the possibility to influence legislation at this vital pre-legislative stage. In the ordinary legislative procedure, the Parliament and the Council of the EU are both veto players whose consent is necessary for legislation to pass. Around $95 \%$ of laws are now decided under this procedure. The policy-making process continues after the legislative procedure is completed. Here the Commission and regulatory agencies play a vital role in implementation, with the latter frequently granted considerable discretion to manage and reconcile incomplete legislative contracts. This leaves interest groups with a range of options to influence the substance of these decisions.

To gain influence, groups first need to get access to European level institutions. Since resources are limited, they must decide which European level policy-makers will be most advantageous for them to target their lobbying effort at. This strategic behavior should vary between group types: to the extent that business groups command greater resources in general and in particular more relevant technical information, they will expect their access-seeking efforts to be more successful compared with other groups. In this paper, we take the unique opportunity to analyze differences in access-seeking strategies at venues across the whole policy cycle including the implementation stage. In this way, we can also draw conclusions on how lobbying efforts at one venue influences choices at others.

Research indicates that business actors are generally overrepresented in the EU, and in political systems more generally (Rasmussen and Carroll 2014; Eising 2004; Greenwood 1997). Additionally, business frequently has very specialized political interests, for which the highly specialized and technical executive and legislative agenda of European institutions provides a congenial environment. This offers business actors numerous opportunities for "niche" or "loophole lobbying", concentrating on very specific aspects of a policy with the aim of minimizing the cost implications while at the same time increasing the benefits for a specific sector (Polk and Schmutzler 2005). In respect to US policy-making, Baumgartner and Leech (2001) have found that business groups are overrepresented in all lobbying activities. Furthermore, almost all policy issues attract lobbying by only a very small number of organizations, often only by one. Moreover, for these issues triggering the interest of only one or two groups, the lobbyists are usually business actors. However, recent research (Dür et al. 2019) has shown that business organizations are frequently less successful than non-business organizations in respect to influencing the policy outputs of the EU.

Furthermore, some institutions are biased toward certain types of interest, so that different groups are favored or disadvantaged by different institutional arrangements (Baumgartner and Jones 1991). In an early study focusing on the 
local level, Stone (1976) found that citizen groups are more influential in open, public forums held for debating community development policies, while business-oriented elites are more likely to get their will in the quieter, more technical and bureaucratic implementation stages. Similarly, while business groups are overrepresented in all main venues in Denmark, they are especially well-equipped to get access to the bureaucracy, whereas citizen groups are overrepresented in parliament compared to their share in the interest group population (Binderkrantz et al. 2015). In their study on multi-level lobbying, Dür and Mateo (2016) also found legislative institutions more prone to listen to non-business interests than executive institutions. For interest groups this means that they should target the venues that offer them the best opportunities to fulfil their objectives. They expect to influence a particular policy more successfully if they manage to change the institutional venue where the decision is made (Pralle 2003). Thus, groups should target the venues that are most favorable to their goals. As a result, there will be differences in the proportion of group types seeking access to a given venue at the European level. However, the goals that interest groups pursue in the political arena are not limited to influencing political decision making. They also include less tangible goals, such as enhanced legitimacy, both of the groups and their cause, improved networks and increased political capital (cf. Ruzza 2011, 2015). This has implications for the relationship between specific venues and specific group types: on the one hand, some venues give interest groups a greater possibility to pull the substance of a decision into the direction of their preferences than others. On the other hand, some access points offer other important goods, like democratic legitimacy, representation, and political capital. While non-business groups should weigh both goals equally, we expect business groups in general to concentrate their resources on the most important decision nodes in the EU. These incentives affect the relative allocation of lobbying resources between the two group types. In the following, we discuss the implications of this argument for each institution in the order of their appearance in the ordinary legislative procedure.

\section{European Commission}

Organized interests have considerable incentives to target the European Commission because of its agenda-setting role in the legislative process. Its DGs take care of drafting legislation and conducting consultations with organized interests. Furthermore, the Commission plays a decisive role in implementing legislation. This dual role makes the Commission an even more important venue, and it is considered to be the most promising stage to influence legislation in the EU (Bouwen 2009; Hull 1993). For this reason, business interests are also highly overrepresented at this stage, even regarding the participation rates in the open stakeholder consultations of the Commission (Marxsen 2015; Rasmussen and Carroll 2014). Furthermore, in order to fulfil its functions and due to its low bureaucratic capabilities, the Commission is highly dependent on the technical knowledge offered by business associations and firms (Coen 2009). 
However, as a consequence of its central role in EU policy-making and for reasons of legitimacy, the Commission goes to considerable lengths to level the interest group playing field, rolling out the metaphorical red carpet to otherwise disadvantaged interests, in particular facilitating the direct participation of civil society organizations in the process (Kohler-Koch 2010; Greenwood 2007; European Commission 2001). While the Commission aligned with business interests in the market-creating phase of completing the single market, it has now an interest to cooperate with civil society organizations in order to regulate this market (Dür et al. 2019). For this reason, the Commission has created its system of open online consultations that facilitates the participation of broader segments of the interest groups universe. Increasing politicization of EU politics could also play a role, as salience is associated with less participation bias in the consultations (Roed and Hansen 2018). Furthermore, the Commission directly funds and even creates EU interest groups (Coen and Bouwen 2009: 8). While group type does not play a role when it comes to the allocation of funds by the Commission (core and other funding) (Crepaz and Hanegraaff 2019), it seems likely that only the provision of 'core funding' is decisive for access. Thus, other funding is generally project-related and therefore not explicitly associated with building lobbying capacity, for example, research and development funding. To illustrate the Commission's activist role, it finances non-governmental organizations (NGOs), sometimes adding a significant portion to their overall annual budget as in the case of European Consumer Organization (BEUC): In 2017, the organization received an operating grant of $€ 1,400,000$ along with other project-related EU funding of $€ 1,034,837$, which together represent half of its annual budget (BEUC 2018). In the words of Mahoney (2004: 444): "The direct role of outright subsidy may be seen as an effort by the EU to promote wider civil society participation, working to lessen some of the endemic biases inherent in the patterns of mobilization of different sectors of society". Moreover, as illustrated above, the impact that Commission funding has on smaller, less-well financed non-business groups will be larger than the one on business or other already better-funded organizations. While resources seem to play a role in influencing the agenda setting of the EU (Binderkrantz and Rasmussen 2015), the Commission aims at creating a neo pluralistic environment, encompassing a wider spectrum of interests than would otherwise have been the case. Especially important in this regard is its highly institutionalized consultation regime, which lowers the costs for interest groups to participate in EU policymaking. As a result, non-business organizations are likely to develop particularly high aspirations to lobby the Commission. We expect that these incentives compensate any advantage that business might have in terms of material resource and technical knowledge when it comes to lobbying:

Hypothesis 1 Business and non-business groups are equally likely to seek access to the Commission.

\section{European Parliament}

In the context of the European Parliament, the (shadow-) rapporteurs and chairs of committees are the most promising lobbying targets, as they play an 
important role in formulating the position the institution takes on a piece of legislation (Hix and Hoyland 2011: 58-59; Mahoney 2008). The rapporteur is the single most influential actor in the Parliament (Hix and Hoyland 2011; Marshall 2010). More than a third of all amendments that make it through committee have been part of their draft reports (Marshall 2010). As a consequence, rapporteurs carefully manage access, since the time they have to talk to interest groups is limited. Conversely, ordinary MEPs are less central to the legislative process, and they are larger in number. As such, they represent contact points via whom an interest group is less likely to influence policies than via the rapporteurs, but whose access opportunities are less restricted. Thus, for non-business groups approaching ordinary MEPs is a less costly alternative in order to have some potential impact on policy-making. Furthermore, these ordinary MEPs provide interest groups with the opportunity to connect to parliamentarians and to demonstrate to their members that they are politically active, creating in this way incentives for potential members to join the organization (Godwin et al. 2013: 95). For their part, MEPs need not only technical, but also political information about the level of public support and/or opposition to a policy, which nonbusiness groups can signal to them because their members and supporters are to a large extent identical to the voters (De Bruycker 2016: 600). While rapporteurs are also interested in political information, they are occupied with drafting amendments to a Commission proposal and thus more in need of technical information business groups can supply.

Of course, both business and non-business groups have an interest in influencing the content of decisions made by EU-level policy-makers. Thus, in respect to the European Parliament, there is a strong incentive for both types of groups to target the rapporteurs. However, in contrast to the Commission, the Parliament has made no institution-wide effort to counterbalance business groups' resource advantage. Moreover, given that the Commission has encouraged non-business organizations to direct a considerable portion of resources to the consultation stage, these organizations are even less well placed to compete in what is arguably the second most advantageous lobbying target. Furthermore, the incentive of non-business groups to lobby the European Parliament might not be as big in relation to business because the directly elected legislative chamber can be considered a natural ally of citizen groups (Dür et al. 2019). We finally expect non-business groups to also have an interest in connecting to parliamentarians to pursue more diffuse goals, such as being represented in parliamentary forums or building political capital. These expectations lead to the following two hypotheses:

Hypothesis 2 Business groups are more likely to seek access to rapporteurs than non-business groups.

Hypothesis 3 Non-business groups are more likely to seek access to ordinary MEPs than business groups. 


\section{Member-state representatives in the Council of the EU}

If groups have not been successful in pulling a legislative proposal into their preferred direction, addressing member-state representatives may be the last resort to prevent or change a legislative proposal. This holds true especially for the influential national diplomats in Coreper, who oversee all legislative processes within the Council and resolve most issues (if agreement has not already been reached in the working groups) before they reach the ministers (Häge 2013). Economic and other structural interests of the member states play an important role in the decision-making processes in the Council (Thomson 2011). Moreover, national governments might be more prone to listen to business, i.e., employer interests, because they are important for generating growth and employment and in this way affect the re-election chances of governments (Bernhagen 2007). Information on the aggregate needs and interests of businesses in the domestic markets are important in this regard (Saurugger 2009; Bouwen 2002). Thus, business groups have an incentive to lobby these institutional venues as they are likely to share their preference for maintaining a frequently market-friendly status quo of EU regulation (Dür et al. 2019). However, owing to the same re-election incentive, national governments also have to take into consideration other types of interests. Yet, while national governments may not discourage the participation of wider societal interests, they do not facilitate the participation of non-business groups in the legislative procedure as actively as the Commission does. As national diplomats have to take into account the domestic constraints of the institution's top level outlined above, we expect that:

Hypothesis 4 Business groups are more likely to seek access to member-state representatives in the Council than non-business groups.

\section{Regulatory lobbying}

Decision making at the European level does not stop when the formal legislative procedure is concluded. The regulatory agencies of the EU have important competences in implementing legislative decisions and are also able to make new regulations. They are involved in the implementation of legislation both by assisting the Commission and providing technical information to this institution and its implementing bodies as well as by their own competence to adopt regulations (Chiti 2013). Majone (1997: 264) describes their operation as "information-based modes of regulation" which ought to be "in tune with current economic, technological and political conditions". On the one hand, they collaborate closely with the Commission while retaining a considerable degree of decision-making autonomy (Trondal 2010). On the other hand, they are controlled to a large extent by appointees of member states on their management boards (Keleman and Majone 2017). Existing studies on EU regulatory agencies (Egeberg and Trondal 2011; Barbieri and Ongaro 2008; Trondal 2010; Keleman 2002) have not addressed the role played by organized interests. One exception is a recent study by Arras and Braun (2018), who 
analyze stakeholder consultations by European regulatory agencies. These scholars find that most regulatory agencies involve stakeholders to a certain degree, including by means of public consultations. However, while acknowledging the importance of increasing the transparency and legitimacy of decisions, the agencies' main motivation is to obtain expertise. Thus, Arras and Braun (2018: 1259) point to a possible dependence of regulators on the regulated industry. Moreover, as they usually operate in a single policy area, European regulatory agencies are especially prone to niche lobbying (Barbieri and Ongaro 2008: 413).

The literature suggests that business groups are much more likely than nonbusiness groups to seek access to regulatory agencies, for four reasons. Firstly, only groups possessing sufficient amounts of material resources as well as technical knowledge of importance to regulatory agencies can address these highly specialized actors successfully. Chubb (1983) has shown that producer groups are more likely to lobby the bureaucracy than citizen groups, and that resource-rich citizen groups are more likely than resource-poor citizen groups to seek access to the bureaucracy. He argues that the marginal costs of lobbying increase rapidly at the point where the congressional decision process ends and the bureaucratic decision making begins. Secondly, business groups are more likely to be affected by the rules set by agencies than other interests. Thirdly, as Dür et al. (2019) have shown, business is more likely to lose in the EU's ordinary legislative procedure. This provides business actors with increased incentives to target their efforts at the implementation stage. Moreover, the US literature has found a business advantage both regarding access to federal agencies as well as in influencing their decisions (McKay and Yackee 2007; Yackee and Yackee 2006; Golden 1998). Regulatory agencies are especially likely to act in accordance with submissions from interest groups if the latter request to keep the rules as is. Golden (1998) has found that, when a commenter requested that the agency keep a rule the same, it accommodated this request in 94 per cent of all cases. Thus, regulatory agencies in the US tend to concede to the wishes of business groups (Yackee 2006) and, when lobbied, have a bias in favor of the status quo. We argue that this logic extends to the case of the EU. Furthermore, a consequence of the Commission's actions in providing incentives for non-business to favor its venues when allocating resources is that, at the regulatory stage in the process, nonbusiness groups will have depleted resources. Because regulatory agencies provide such a fertile ground for the efforts of business lobbyists, we expect that

Hypothesis 5 Business groups are more likely to seek access to European regulatory agencies than non-business groups. 


\section{Research design}

To analyze the patterns and determinants of inside lobbying strategies, we use an original survey data set on EU-level interest groups. In the web-based INTEREURO Interest Group Survey (Beyers et al. 2015), we targeted EU-level interest groups (both EU peak associations and national organizations with a presence in Brussels) that show at least a minimum degree of interest in EU policy-making processes. To demarcate the EU interest group population, we used the EU's Transparency register, ${ }^{1}$ the OECKL Directory $(2014)^{2}$ and lists of actors identified in issue-centered research reported in Beyers et al. (2014). In this way, we aimed at getting a complete picture of the EU interest group universe, instead of relying on one source only (e.g., the Transparency Register). The study focuses on interest associations; individual firms have not been included in the sample. The result yielded a sample of 2038 interest groups, which were invited to take part in the survey. The questionnaire was in the field from 9 March until 2 July 2015. 734 questionnaires have been completed, leading to a response rate of 36 per cent. The distribution of these groups is almost evenly split between business (52.7\%) and other groups (47.3\%).

\section{Dependent variable: access seeking}

The dependent variable is the frequency with which groups have sought access to each major EU institution. The precise wording of the survey question is: "During the last 12 months, how often has your group actively sought access to the following EU-level institutions and agencies in order to influence public policies?" Respondents could choose between the following categories: "We did not seek access", "At least once", "At least once every three months", "At least once a month", "At least once a week". These categories have been assigned integers from 1 ("did not seek access") to 5 ("At least once a week"). Using this scale, the frequency of access has been probed for five different institutional actors in four venues at the EU level, which include the three main legislative institutions, the Commission, Council and Parliament, as well as European regulatory agencies. Regarding the Commission, we can analyze access seeking strategies at the crucial desk level (DGs). We distinguish between two different venues in the European Parliament: the (shadow-) rapporteurs and ordinary MEPs. In the Council, we look at lobbying efforts aimed at diplomats in Coreper, since these play an important role in shaping the outcome of the policy-making process. Finally, we investigate access-seeking to regulatory agencies, which are an important access point to affect policy implementation. Thus, our analysis will use five different dependent variables.

\footnotetext{
${ }^{1}$ Transparency Register, available at: http://ec.europa.eu/transparencyregister/public/homePage.do?local $\mathrm{e}=$ en\#en, accessed 16 October 2014.

${ }^{2}$ OECKL. Directory of Public Affairs-Europe and International Alliances 2014/2015, 19th edition, Wien: Festland Verlag.
} 


\section{Explanatory and control variables}

The main explanatory variable in this analysis is group type. It is coded 1 for business and 0 for other groups. Coding was carried out by two student assistants. After a period of training in order to check and improve the intercoder reliability, both coded 100 organizations independently of each other. Krippendorff's alpha for these 100 observations was 0.93 . From then onward, each coder coded a part of the sample independently, but they discussed cases in which they were uncertain whether a group belongs to the business or non-business category. Fourteen cases which they could not agree on were decided by a researcher. Professional associations were coded according to the status of their members as business or non-business. If members are mostly employees, the professional organization was coded as nonbusiness, as this kind of professional associations is similar to "white collar" unions (c.f. Kjellberg 2013). If most of the members are self-employed, the organization was coded as business.

Group type is not the only variable that explains variation in access seeking to different venues in the multi-level system of the EU. Therefore, a number of control variables from the survey will be used in the analysis. Regardless of whether an organization represents business or non-business interests, its level of Europeanization should play a role in its lobbying strategy. This should hold especially regarding the European Commission, as this institution fosters the Europeanization of interest groups. Bouwen (2004) has found that European associations enjoy the highest degree of access to the Commission. Furthermore, groups do not only have the possibility to target different venues at the European level to influence public policies. Alternatively, they can use the national route (Beyers 2002). The more time groups spend at the European level, the more likely they are also to actively seek access to the supranational institutions. The percentage of time an interest group spends at the European level relative to both the regional and international/global level will be used as an indicator for the degree of Europeanization of a group.

Beside time constraints, the amount of resources spent at the EU-level constrains the inside lobbying strategies of groups. Thus, the percentage of the total resources of the organization that is spent focusing on EU policies is added as a control variable to the analysis. It consists of four categories: "Less than 25\%", "Between 25 and 50\%", "Between 50 and 75\%", and "More than 75\%", coded 1-4. Furthermore, the more time a group devotes to insider strategies, the more frequently it should actively seek access to EU institutions. Thus, the percentage of time a group spends on insider, in relation to outsider strategies, has been added as a control variable. The question reads as follows: "Approximately what percentage of your organization's time is devoted to insider strategies that involve activities such as direct contact with the Commission, member state representatives or policy officials in the European Parliament AND outsider strategies that involve press releases, coordinating letter writing, e-mailing or social media campaigns, rallies and demonstrations?" Respondents were asked to write approximate percentages for insider and outsider strategies into two separate fields in the web form.

The age of an organization is an indicator for its stability, credibility, success and the quality of its network. Organizations that have a history of active involvement 
Table 1 Summary statistics

\begin{tabular}{|c|c|c|c|c|c|c|}
\hline Variable & $N$ & Mean & $\mathrm{SD}$ & Minimum & Median & Maximum \\
\hline Access: Commission DGs & 659 & & & 1 & 3 & 5 \\
\hline Access: (Shadow) Rapporteur & 639 & & & 1 & 2 & 5 \\
\hline Access: Ordinary MEP & 646 & & & 1 & 2 & 5 \\
\hline Access: Coreper & 639 & & & 1 & 1 & 5 \\
\hline Access: Regulatory Agency & 640 & & & 1 & 1 & 5 \\
\hline Business Actor & 887 & 0.53 & 0.5 & 0 & 1 & 1 \\
\hline Insider Outsider & 612 & 59.99 & 25.02 & 0 & 60 & 100 \\
\hline Percent EU Lobbying & 706 & 64.93 & 1.11 & 0 & 70 & 100 \\
\hline Technical Information & 639 & & & 1 & 2 & 5 \\
\hline Percent EU resources & 695 & & & 1 & 3 & 5 \\
\hline Budget & 728 & & & 1 & 2 & 6 \\
\hline Age of organization & 864 & 27.76 & 25.82 & 0 & 21 & 183 \\
\hline
\end{tabular}

in the relevant policy community are more likely to have established networks with other groups and policy-makers (Mahoney 2004: 452). Next, insider strategies are conditioned by a groups' overall resource base. The more material resources a group possesses, the more it can target different venues at the European level (Ehrlich and Jones 2017: 13). We use the budget variable of the survey, which has six categories (in $€$ ): Under 100,$000 ; 100,000-500,000 ; 500,000-1$ million; 1 million-5 million; 5 million-10 million; over 10 million. Lastly, technical information is an important resource that EU institutions demand, especially due to their own limited bureaucratic resources. The survey contains a question asking respondents how often their organization had presented research results or technical information to EU-level policy-makers during the last 12 months. The response categories are "We did not do this", "At least once", "At least once every 3 months", "At least once a month", "At least once a week". Table 1 lists summary statistics for all variables.

\section{Results}

Given the nature of the dependent variables, we conduct our multivariate analysis using ordered logistic regression. This is done separately for each of the five EUlevel venues that we have developed expectations for. ${ }^{3}$ The results are presented in Table 2, which reports exponentiated coefficients (odds ratios). As indicated by reasonably high Nagelkerke Pseudo-R2s, all models predict access seeking rather well.

\footnotetext{
${ }^{3}$ We have performed Brant tests (Brant 1990) for all models and the parallel regression assumption always holds.
} 
Table 2 Predicting access sought by interest groups, by EU venue

\begin{tabular}{|c|c|c|c|c|c|}
\hline & $\begin{array}{l}\text { Model } 1 \\
\text { Commission } \\
\text { DGs }\end{array}$ & $\begin{array}{l}\text { Model } 2 \\
\text { (Shadow) } \\
\text { Rapporteurs }\end{array}$ & $\begin{array}{l}\text { Model } 3 \\
\text { Ordinary MEPs }\end{array}$ & $\begin{array}{l}\text { Model } 4 \\
\text { Coreper }\end{array}$ & $\begin{array}{l}\text { Model } 5 \\
\text { Regulatory } \\
\text { agencies }\end{array}$ \\
\hline Business & $\begin{array}{l}1.117 \\
(0.186)\end{array}$ & $\begin{array}{l}1.475^{* *} \\
(0.254)\end{array}$ & $\begin{array}{l}0.693 * * \\
(0.114)\end{array}$ & $\begin{array}{l}1.17 \\
(0.248)\end{array}$ & $\begin{array}{l}2.282 * * * \\
(0.428)\end{array}$ \\
\hline Insider/outsider & $\begin{array}{l}1.01^{* * * *} \\
(0.003)\end{array}$ & $\begin{array}{l}1.002 \\
(0.004)\end{array}$ & $\begin{array}{l}0.997 \\
(0.003)\end{array}$ & $\begin{array}{l}1.003 \\
(0.004)\end{array}$ & $\begin{array}{l}0.998 \\
(0.004)\end{array}$ \\
\hline Percent EU lobbying & $\begin{array}{l}1.012^{* * * *} \\
(0.003)\end{array}$ & $\begin{array}{l}1.003 \\
(0.003)\end{array}$ & $\begin{array}{l}1 \\
(0.003)\end{array}$ & $\begin{array}{l}0.99 * * \\
(0.004)\end{array}$ & $\begin{array}{l}1 \\
(0.004)\end{array}$ \\
\hline Technical information & $\begin{array}{l}3.149 * * * \\
(0.327)\end{array}$ & $\begin{array}{l}2.011^{* * * *} \\
(0.195)\end{array}$ & $\begin{array}{l}2.205^{* * * *} \\
(0.210)\end{array}$ & $\begin{array}{l}1.863 * * * \\
(0.211)\end{array}$ & $\begin{array}{l}1.905^{* * * *} \\
(0.196)\end{array}$ \\
\hline Percent EU resources & $\begin{array}{l}1.309 * * * \\
(0.097)\end{array}$ & $\begin{array}{l}1.486^{* * * *} \\
(0.116)\end{array}$ & $\begin{array}{l}1.333 * * * \\
(0.097)\end{array}$ & $\begin{array}{l}1.233^{*} \\
(0.118)\end{array}$ & $\begin{array}{l}1.227^{* *} \\
(0.1)\end{array}$ \\
\hline Budget & $\begin{array}{l}1.592 * * * \\
(0.121)\end{array}$ & $\begin{array}{l}1.554 * * * \\
(0.116)\end{array}$ & $\begin{array}{l}1.232 * * * \\
(0.09)\end{array}$ & $\begin{array}{l}1.267 * * * \\
(0.111)\end{array}$ & $\begin{array}{l}1.249 * * * \\
(0.099)\end{array}$ \\
\hline Age of organization & $\begin{array}{l}0.997 \\
(0.004)\end{array}$ & $\begin{array}{l}1.003 \\
(0.004)\end{array}$ & $\begin{array}{l}1.005 \\
(0.004)\end{array}$ & $\begin{array}{l}1.012 * * * \\
(0.004)\end{array}$ & $\begin{array}{l}0.992 * \\
(0.004)\end{array}$ \\
\hline Nagelkerke Pseudo- $R^{2}$ & 0.73 & 0.64 & 0.64 & 0.54 & 0.53 \\
\hline$N$ & 533 & 524 & 526 & 522 & 524 \\
\hline
\end{tabular}

Cell entries are exponentiated coefficients; with standard errors in parentheses; ${ }^{*} p<0.1, * * p<0.05$, $* * * p<0.01$

\section{European Commission}

Our theoretical approach assumes that the Commission occupies a unique role in structuring the nature of its interactions with interest groups. We have argued that a consequence of Commission actions to level the playing field for interest group access would be that non-business groups develop aspirations to lobby the Commission on a par with business. Therefore, there should be no observable difference between business and non-business behavior (Hypothesis 1). To assess this expectation, we analyze access to Commission DGs (Model 1) and regress on the group type variable. The results lend support to our argument, as we cannot reject the null hypothesis of no difference between business and non-business lobbying at the level of the Commission. ${ }^{4}$

\footnotetext{
${ }^{4}$ It is strictly speaking not possible to conclude that there is no effect when $p>\alpha$, as the test might simply have lacked the statistical power to detect a true effect. Given our sample size of $n=533$, we expect that the lack of a statistically significant difference between business and non-business groups implies statistical support to Hypothesis 1, according to which the difference between business and non-business groups is zero. To check whether this is the case, we have performed an additional test of equivalence, with the null hypothesis that business and non-business groups are different by at least as much as an equivalence interval defined a level of tolerance. Formally, $\mathrm{H}_{0}:\left|\mathrm{b}_{\text {business }}\right| \geq \Delta$, where the equivalence interval ranges from $b_{\text {business }}-\Delta$ to $b_{\text {business }}+\Delta$. This translates directly into two one-sided null hypotheses: $\mathrm{H}_{0} 1: \Delta-\mathrm{b}_{\text {business }} \leq 0$; and $\mathrm{H}_{0} 2: \Delta * \mathrm{~b}_{\text {business }} \leq 0$. Specifying reasonable upper and lower equivalence bounds for the odds ratio of $b_{\text {business }}$ at 0.737 (lower) and 1.731 upper, we can reject the null hypothesis of difference at a level of significance of $p<0.5$. Thus, we can conclude equivalence and formally infer that business and non-business organizations are equally likely to seek access to the Commission.
} 
The results presented in Model 1 also serve to complete the picture of how DGs structure the nature of their interactions with organized interests. Here, the positive and significant effect of the 'insider/outsider' variable indicates that above all other venues it is the Commission that privileges organizations that commit to an insider strategy; a behavior associated with an institutionalized form of policy-making. For all other venues the effect of this variable is insignificant. A similar sense of the Commission as a venue for organizations committed to the supranational path is picked up with the 'percent EU lobbying' variable, as those organizations that are most strongly focused on EU-level lobbying are more likely to direct their lobbying efforts to the Commission. The character of lobbying DGs is further differentiated from all other EU venues with respect to the role of technical information. Reassuringly, in keeping with the literature, we find that, 'technical information' is positively associated with seeking access to all venues. But interestingly in the case of the Commission this effect is close to double that for any other venue, suggesting that this requirement is most advantageous at the agenda-setting phase; with a 1 point (out of 5) increase in the reported frequency of presenting technical knowledge associated with a $215 \%$ increase in the odds of a higher intention to lobby (moving up the 5-point scale) the Commission.

\section{European Parliament}

To test the contrasting expectations for business groups' lobbying in the European Parliament, we estimate Models 2 ((Shadow) Rapporteurs) and 3 (ordinary MEPs). With respect to the rapporteurs we find that, in support of Hypothesis 2, business groups are associated with a $48 \%$ increase in the odds of being in a category of more frequent lobbying than that selected by non-business groups. Conversely, the odds of business groups lobbying ordinary MEPs at a higher level than non-business groups are estimated to be $31 \%$ lower (all significant at the 0.05 level), lending considerable support to Hypothesis 3. Thus, while business groups concentrate their efforts on influencing the decisions of the Parliament, non-business interests have a higher intention to build political capital by connecting as well to ordinary parliamentarians.

\section{Member state representatives in the Council of the EU}

The expectation for the Council is that business groups lobby national diplomats in Coreper more frequently than non-business groups (Hypothesis 4). However, the results presented in Model 4 do not support this argument, as the group type variable is not significant. Interestingly, the model yields some intuitive results in respect to the percentage of EU lobbying. Here the exponentiated coefficient is statistically significant $(p<0.5)$ and smaller than 1 , indicating that this EU venue favors lobbying from associations that are predominantly active at the national level. Furthermore, organizational age is positively associated with seeking access to this venue. This might be due to the fact that - at least at the national level with established 
Table 3 Overview of results

\begin{tabular}{ll}
\hline Hypothesis & Supported \\
\hline $\begin{array}{l}\text { Commission: Similar Likelihood Of Access-Seeking By Business And Non-Business } \\
\text { Groups (H1) }\end{array}$ & Yes \\
Parliament: Business groups are more likely to seek access to rapporteurs (H2) & Yes \\
Non-business groups are more likely to seek access to ordinary MEPs (H3) & Yes \\
Council: Business groups are more likely to seek access (H4) & No \\
Regulatory Agencies: Business groups are more likely to seek access (H5) & Yes \\
\hline
\end{tabular}

interest group systems - the age of an organization is considered to be an indicator for its credibility.

\section{Regulatory lobbying}

To assess the argument that business groups seek to mitigate losses from the legislative phase of the policy process by pursuing a strategy of access-seeking to European regulatory agencies (hypotheses 5), the final model (5) is considered. Here, the exponentiated coefficient for business is significant and in the expected direction. This indicates that business groups, when compared to non-business groups, are associated with a $128 \%$ increase in their odds of seeking to lobby regulatory agencies.

Finally, across all models we also controlled for the 'age of organization', the size of its 'budget' and the percentage of 'resources spent at the EU level'. We found that, in keeping with the literature, increases in organizations' financial resources are positively associated with their intention to lobby. Furthermore, in all models, spending a larger share of resources at the EU level is positively related to the lobbying efforts of interest groups across venues. However, organizational age appears to be only sporadically associated with access-seeking. Credibility could explain the positive effect of organizational age on the intention to lobbying the Council. However, when it comes to lobbying at the EU level, the supranational institutions also have an incentive to cooperate with European associations, which are younger than their national counterparts. Table 3 gives an overview of the results in the light of our hypotheses.

\section{Conclusions}

In this paper, we have analyzed the access-seeking strategies of interest groups at the EU's key policy-making venues. Drawing on insights from the literatures on business lobbying, venue shopping and elite pluralism, we developed a theoretical argument and testable hypotheses to account for differences and similarities in the extent to which interest groups seek access to the main EU policy-making venues. Thereby, our analysis contributes to the understanding of strategies of inside lobbying by different types of interest group at venues involved in all stages of the policy-making 
process in the EU and within two different venues in the European Parliament. Our results yield insights regarding state-society relations in a broader sense, and, in particular, an often-expected business bias in the accessibility of European institutions.

In our argument we have paid particular attention to the consequences of the Commission's actions to draw non-business interests into the consultation phase of the process. Our expectations regarding access-seeking to the European Commission have been supported. The institution seems to have been successful in its attempts to neutralize business dominance by creating a neo pluralistic environment that is targeted by both business and non-business groups in a broadly equal manner. This leads to similar frequencies of inside lobbying pursued by business and nonbusiness groups regarding this institution. Considering how important the position of the Commission is in EU policy-making, this is a noteworthy finding. The institution is often criticized for heavily relying on the expertise of interest groups because of its own low bureaucratic capacities. However, the Commission also seems to be successful regarding its efforts to encourage the broader civil society to contribute to the deliberations on its legislative initiatives.

Furthermore, our argument that business groups have relatively higher incentives to seek access to the rapporteurs in the European Parliament in order to influence legislation, while non-business groups are relatively more interested in connecting to parliamentarians in order to represent their members and build political capital is supported: Business groups lobby rapporteurs more frequently than non-business groups, and non-business groups lobby ordinary MEPs more frequently than business groups. These results support the argument that non-business groups' proclivity to target ordinary MEPs reflects the need of satisfying their members, while business groups are more firmly focused on attempting to secure legislative gains. The finding might reflect the fact that accessing ordinary MEPs is less costly than lobbying the rapporteurs. While non-business interests have already spent much of their resources at the Commission stage, at the stage of the European Parliament decision-making resource-endowed business groups can still afford to target rapporteurs. Thus, in differentiating between what are likely to be the most and least influential actors within the Parliament, we obtain a more comprehensive picture of the accessibility of one of the EU's main legislative bodies. In this way, we have to qualify previous findings of equal access to the European Parliament for business and non-business interests (e.g., Dür and Mateo 2016). However, while business groups might provide the Parliament with important technical knowledge it needs to compete with the other two legislative institutions, so far these lobbying efforts do not seem to have biased the legislative body in favor of business interests (Dür et al. 2019). Furthermore, we have found no support for our expectation that business groups lobby the representatives of member states in the Council more frequently than other interests. Hence, the Council, like the Commission, seems to be open to a broad range of interests and is not as biased toward business as is often expected. This might imply that national representatives structure access in such a way as to demonstrate that different nationally derived policy perspectives are taken into account. Re-election incentives at the top level of this institution might be important even for the diplomats structuring their interactions with interest groups given the Council members' ties to their national constituents. From the perspective of state-society relations and the 
democratic quality of EU policy-making, this finding is as encouraging as the similarities in access-seeking to the Commission by business and non-business actors.

Finally, our study provides new insights into regulatory lobbying in the EU. There is strong evidence to suggest that business groups attempt to mitigate any losses they might have incurred during the legislative phase, as they are more likely to lobby regulatory agencies than are non-business groups. Moreover, the lower non-business activity found at regulatory agencies corresponds with our argument that after responding to the Commission's selective incentives these organizations simply lack the resources to engage in lobbying at this final venue. Non-business groups might also be less affected by, and thus to a lesser extent interested in changing, the highly specific decisions of these institutions than business groups lobbying more frequently in the niches of policy-making. In sum, while there is no evidence of a business bias of the European Commission at the starting point of the EU's legislative process, business groups might be able to pull the outcome back in their preferred direction toward the end of the process. However, it is doubtful that this can fully compensate for any previous legislative losses. Further studying the differences between business and non-business groups' access to EU regulatory agencies as well as influencing their decisions would be a promising field of research.

Acknowledgements We thank Caelesta Braun and Marcel Hanegraaff for helpful comments on earlier versions of this article. Vanessa Bausch and Carola Majer offered valuable research assistance.

Funding Open Access funding enabled and organized by Projekt DEAL.

\section{Compliance with ethical standards}

Conflict of interest On behalf of all authors, the corresponding author states that there is no conflict of interest.

Open Access This article is licensed under a Creative Commons Attribution 4.0 International License, which permits use, sharing, adaptation, distribution and reproduction in any medium or format, as long as you give appropriate credit to the original author(s) and the source, provide a link to the Creative Commons licence, and indicate if changes were made. The images or other third party material in this article are included in the article's Creative Commons licence, unless indicated otherwise in a credit line to the material. If material is not included in the article's Creative Commons licence and your intended use is not permitted by statutory regulation or exceeds the permitted use, you will need to obtain permission directly from the copyright holder. To view a copy of this licence, visit http://creativecommons.org/licenses/by/4.0/.

\section{References}

Ainsworth, Scott. 1993. Regulating Lobbyists and Interest Group Influence. The Journal of Politics 55(1): 41-56.

Arras, Sarah, and Caelesta Braun. 2018. Stakeholders Wanted! Why and How European Union Agencies Involve Non-state Stakeholders. Journal of European Public Policy 25(9): 1257-1275.

Austen-Smith, David. 1993. Information and Influence: Lobbying for Agendas and Votes. American Journal of Political Science 37(3): 799-833. 
Barbieri, Dario, and Edoardo Ongaro. 2008. EU Agencies: What is Common and What is Distinctive Compared with National-Level Public Agencies. International Review of Administrative Sciences 74(3): 395-420.

Baumgartner, Frank R., and Beth L. Leech. 2001. Interest Niches and Policy Bandwagons: Patterns of Interest Group Involvement in National Politics. Journal of Politics 63(4): 1191-1213.

Baumgartner, Frank R., and Bryan D. Jones. 1991. Agenda Dynamics and Policy Subsystems. The Journal of Politics 53(4): 1044-1074.

Baumgartner, Frank R., and Bryan D. Jones. 2009. Agendas and Instability in American Politics. Chicago: The University of Chicago Press.

Beer, Samuel. 1965. Modern British Politics. A Study of Parties and Pressure Group. London: Faber.

Bernhagen, Patrick. 2007. The Political Power of Business. Structure and Information in Public Policymaking. London: Routledge.

BEUC. 2018. Annual Report 2017. In: https://www.beuc.eu/publications/beuc-x-2018-038_annual_repor t_2017.pdf. Accessed 24 April 2019.

Beyers, Jan. 2002. Gaining and Seeking Access: The European Adaptation of Domestic Interest Associations. European Journal of Political Research 41(5): 585-612.

Beyers, Jan. 2004. Voice and Access. Political Practices of European Interest Associations. European Union Politics 5(2): 211-240.

Beyers, Jan, Laura Chaqués Bonafont, Andreas Dür, Rainer Eising, Danica Fink-Hafner, David Lowery, Christine Mahoney, William Maloney, and Daniel Naurin. 2014. The INTEREURO Project: Logic and Structure. Interest Groups \& Advocacy 3(2): 126-140.

Beyers, Jan, Patrick Bernhagen, Caelesta Braun, Danica Fink-Hafner, Frederik Heylen, William Maloney, Daniel Naurin and Dominic Pakull. 2015. INTEREURO Interest Group Survey Questionnaire (Edition: March 2015). University of Antwerp.

Binderkrantz, Anne Skorkjær, Peter Munk Christiansen, and Helene Helboe Pedersen. 2015. Interest Group Access to the Bureaucracy, Parliament, and the Media. Governance 28(1): 95-112.

Binderkrantz, Anne Skorkjær, and Anne Rasmussen. 2015. Comparing the Domestic and the EU Lobbying Context: Perceived Agenda-setting Influence in the Multi-level System of the European Union. Journal of European Public Policy 22(4): 552-569.

Bouwen, Pieter. 2002. Corporate Lobbying in the European Union. Journal of European Public Policy 9(3): 365-390.

Bouwen, Pieter. 2004. Exchanging Access Goods for Access: A Comparative Study of Business Lobbying in the European Union Institutions. European Journal of Political Research 43(3): 337-369.

Bouwen, Pieter. 2009. The European Commission. In Lobbying in the European Union. Institutions, Actors, and Issues, ed. David Coen and Jeremy Richardson, 19-38. Oxford: Oxford University Press.

Brant, Rollin. 1990. Assessing Proportionality in the Proportional Odds Model for Ordinal Logistic Regression. Biometrics 46(4): 1171.

Broscheid, Andreas, and David Coen. 2003. Insider and Outsider Lobbying of the European Commission. European Union Politics 4(2): 165-189.

Chiti, Edoardo. 2013. European Agencies' Rulemaking: Powers, Procedures and Assessment. European Law Journal 19(1): 93-110.

Chubb, John E. 1983. Interest Groups and the Bureaucracy. The Politics of Energy. Stanford: Stanford University Press.

Coen, David. 2009. Business Lobbying in the European Union. In Lobbying the European Union. Institutions, Actors, and Issues, ed. David Coen and Jeremy Richardson, 145-168. Oxford: Oxford University Press.

Coen, David, and Pieter Bouwen. 2009. Lobbying the European Union. Institutions, Actors, and Issues. Oxford: Oxford University Press.

Crepaz, Michele, and Marcel Hanegraaff. 2019. The Funding of Interest Groups in the EU: Are the Rich Getting Richer? Jorunal of European Public Policy 27(1): 102-121.

Dahl, Robert A. 1989. Democracy and its Critics. New Haven/London: Yale University Press.

De Angelis, Gabriele. 2017. Political Legitimacy and the European Crisis: Analysis of a Faltering Project. European Politics and Society 18(3): 291-300.

De Bruycker, Iskander. 2016. Pressure and Expertise: Explaining the Information Supply of Interest Groups in EU Legislative Lobbying. Journal of Common Market Studies 54(3): 599-616.

Dür, Andreas, David Marshall, and Patrick Bernhagen. 2019. The Political Influence of Business in the European Union. Ann Arbor: University of Michigan Press. 
Dür, Andreas, and Gemma Mateo. 2016. Insiders Versus Outsiders. Interest Group Politics in Multilevel Europe. Oxford: Oxford University Press.

Egeberg, Morten, and Jarle Trondal. 2011. EU-Level Agencies: New Executive Centre Formation or Vehicles for National Control? Journal of European Public Policy 18(6): 868-887.

Ehrlich, Sean D., and Eryn Jones. 2017. Whom Do European Corporations Lobby? The Domestic Institutional Determinants of Interest Group Activity in the European Union. Business and Politics 18(4): $467-488$.

Eising, Rainer. 2004. Multilevel Governance and Business Interests in the European Union. Governance 17(2): 211-245.

European Commission. 2001. European Governance. A White Paper, COM (2001) 428 final, Brussels, 25/07/2001.

Godwin, Ken, Scott H. Ainsworth, and Erik Godwin. 2013. Lobbying and Policymaking. The Public Pursuit of Private Interests. Thousand Oaks: CQ Press.

Golden, Marissa Martino. 1998. Interest Groups in the Rule-Making Process: Who Participates? Whose Voices Get Heard? Journal of Public Administration Research and Theory: J-PART 8(2): 245-270.

Grant, Wyn. 2000. Pressure Groups and British Politics. Basingstoke: Macmillan.

Greenwood, Justin. 1997. Representing Interests in the European Union. Basingstoke: Palgrave Macmillan.

Greenwood, Justin. 2007. Organized Civil Society and Democratic Legitimacy in the European Union. British Journal of Political Science 37(2): 333-357.

Häge, Frank M. 2013. Bureaucrats as Lawmakers. Committee Decision-Making in the EU Council of Ministers. London: Routledge.

Hall, Richard L., and Alan V. Deardorff. 2006. Lobbying as Legislative Subsidy. The American Political Science Review 100(1): 69-84.

Hall, Richard L., and Frank W. Wayman. 1990. Buying Time: Moneyed Interests and the Mobilization of Bias in Congressional Committees. The American Political Science Review 84(3): 797-820.

Hanegraaff, Marcel, and Joost Berkhout. 2019. More Business as Usual? Explaining Business Bias across Issues and Institutions in the European Union. Journal of European Public Policy 26(6): 843-862.

Hansen, John Mark. 1991. Gaining Access: Congress and the Farm Lobby, 1919-1981. Chicago: University of Chicago Press.

Hix, Simon, and Bjorn Hoyland. 2011. The Political System of the European Union. 3rd ed. Basingstoke: Palgrave Macmillan.

Holyoke, Thomas T., Heath Brown, and Jeffrey R. Henig. 2012. Shopping in the Political Arena. State and Local Government Review 44(1): 9-20.

Hull, Robert. 1993. Lobbying Brussels: A View from within. In Lobbying in the European Community, ed. Sonia Mazey and Jeremy Richardson, 82-92. Oxford: Oxford University Press.

Keleman, Daniel R. 2002. The Politics of 'Eurocratic' Structure and the New European Agencies. West European Politics 25(4): 93-118.

Keleman, Daniel R., and Giandomenico Majone. 2017. European Agencies: Managing Europeanization. In The Institutions of the European Union, ed. Dermot Hodson and John Peterson, 236-257. Oxford: Oxford University Press.

Kjellberg, Anders. 2013. Union Density and Specialist/Professional Unions in Sweden. In Studies in Social Policy, Industrial Relations, Working Life and Mobility. Research Reports 2013(2).

Knoke, David, Franz Urban Pappi, Jeffrey Broadbent, and Yutaka Tsujinaka. 1996. Comparing Policy Networks: Labor Politics in the US, Germany, and Japan. Cambridge: Cambridge University Press.

Kohler-Koch, Beate. 2010. Civil Society and EU Democracy: 'Astroturf' Representation? Journal of European Public Policy 17(1): 100-116.

Kohler-Koch, Beate, Peter Kotzian, and Christine Quittkat. 2017. The Multilevel Interest Representation of National Business Associations. West European Politics 40(5): 1046-1065.

Lehmann, William. 2009. The European Parliament. In Lobbying the European Union: Institutions, Actors, and Issues, ed. David Coen and Jeremy Richardson, 39-69. Oxford: Oxford University Press.

Mahoney, Christine. 2004. The Power of Institutions. State and Interest Group Activity in the European Union. European Union Politics 5(4): 441-466.

Mahoney, Christine. 2008. Brussels Versus the Beltway. Advocacy in the United States and the European Union. Washington, D.C.: Georgetown University Press.

Majone, Giandomenico. 1997. The New European Agencies: Regulation by Information. Journal of European Public Policy 4(2): 262-275. 
Marshall, David. 2010. Who to Lobby and When: Institutional Determinants of Interest Group Strategies in European Parliament Committees. European Union Politics 11(4): 553-575.

Marxsen, Christian. 2015. Open Stakeholder Consultations at the European Level: Voice of the Citizens? European Law Journal 21(2): 257-280.

McKay, Amy, and Susan Webb Yackee. 2007. Interest Group Competition on Federal Agency Rules. American Politics Research 35(3): 336-357.

Polk, Andreas, and Armin Schmutzler. 2005. Lobbying against Environmental Regulation vs. Lobbying for Loopholes. European Journal of Political Economy 21(4): 915-931.

Pollack, Mark A. 1997. Delegation, Agency, and Agenda Setting in the European Community. International Organization 51(1): 99-134.

Pralle, Sarah B. 2003. Venue Shopping, Political Strategy, and Policy Change: The Internationalization of Canadian Forest Advocacy. Journal of Public Policy 23(3): 233-260.

Princen, Sebastiaan, and Bart Kerremans. 2008. Opportunity Structures in the EU Multi-Level System. West European Politics 31(6): 1129-1146.

Rasmussen, Anne, and Brendan J. Carroll. 2014. Determinants of Upper-Class Dominance in the Heavenly Chorus: Lessons from European Union Online Consultations. British Journal of Political Science 44(2): 445-459.

Richardson, Jeremy John, and A.G. Jordan. 1979. Governing under Pressure: The Policy Process in a Post-parliamentary Democracy. Oxford: Martin Robertson.

Roed, Maiken, and Vibeke Woien Hansen. 2018. Explaining Participation Bias in the European Commission's Online Consultations. The Struggle for Policy Gain without too Much Pain. Journal of Common Market Studies 56(6): 1446-1461.

Ruzza, Carlo. 2011. Social Movements and the European Interest Intermediation of Public Interest Groups. Journal of European Integration 33(4): 453-469.

Ruzza, Carlo. 2015. Changes in the Field of EU Civil Society Organisations: Institutionalisation, Differentiation and Challengers. In EU Civil Society, ed. Håkan Johansson and Sara Kalm, 23-42. London: Palgrave Macmillan.

Saurugger, Sabine. 2009. COREPER and National Governments. In Lobbying the European Union. Institutions, Actors and Issues, ed. David Coen and Jeremy Richardson, 105-127. Oxford: Oxford University Press.

Schlozman, Kay Lehman, and John T. Tierney. 1986. Organized Interests and American Democracy. New York: Harper \& Row.

Smith, Richard A. 1984. Advocacy, Interpretation, and Influence in the U.S. Congress. The American Political Science Review 78(1): 44-63.

Stone, Clarence N. 1976. Economic Growth and Neighborhood Discontent. Chapel Hill: University of North Carolina Press.

Su, Tie-ting, Alan Neustadtl, and Alan Neustadtl. 1995. Business and the Conservative Shift: Corporate PAC Contributions, 1976-1980. Social Science Quarterly 76(3): 20-40.

Thomson, Robert. 2011. Resolving Controversy in the European Union. Legislative Decision-Making before and after Enlargement. Cambridge: Cambridge University Press.

Treib, Oliver. 2014. The Voter Says No, but Nobody Listens: Causes and Consequences of the Eurosceptic Vote in the 2014 European Elections. Journal of European Public Policy 21(10): 1541-1554.

Trondal, Jarle. 2010. An Emergent European Executive Order. Oxford: Oxford University Press.

Truman, David B. 1951. The Governmental Process: Political Interests and Public Opinion. New York: Alfred A. Knopf.

Walker, Jack L. 1991. Mobilizing Interest Groups in America. Patrons, Professions, and Social Movements. Ann Arbor: University of Michigan Press.

Yackee, Susan Webb. 2006. Sweet-Talking the Fourth Branch: The Influence of Interest Group Comments on Federal Agency Rulemaking. Journal of Public Administration Research and Theory 16(1): 103-124.

Yackee, Jason Webb, and Susan Webb Yackee. 2006. A Bias Towards Business? Assessing Interest Group Influence on the U.S. Bureaucracy. Journal of Politics 68(1): 128-139.

Publisher's Note Springer Nature remains neutral with regard to jurisdictional claims in published maps and institutional affiliations. 